\title{
Impact of dietary manipulation on nutrient flows and greenhouse gas emissions in cattle
}

\author{
Ermias Kebreab ${ }^{1}$, Anders Strathe ${ }^{1}$, James Fadel $^{1}$, Luis Moraes $^{1}$, James France ${ }^{2}$ \\ 1 Department of Animal Science, University of California, Davis, 95616, USA. \\ 2 Department of Animal and Poultry Science, University of Guelph, Canada.
}

\begin{abstract}
The growing global demand for meat and particularly in countries such as Brazil is expected to increase intensive animal production. Consequently the main pollutants of interest are nitrogen $(\mathrm{N})$, phosphorus $(\mathrm{P})$ and greenhouse gases (GHG). Nitrogen can be a problem through nitrate leaching to water bodies, ammonia, and nitrous oxide emissions to air. Phosphorus loading in soil from manure application can be the main issue due to the tendency of P to accumulate in soil and leach to groundwater and rivers. The sources of agricultural GHG emissions include methane from enteric fermentation, manure storage and spreading, and nitrous oxide mainly from application of manure on land. Dietary manipulation has proven to be an effective tool to reduce nutrient/mineral pollution and GHG emissions. Several studies have shown that decreasing crude protein in the diet could reduce $\mathrm{N}$ excretion and ammonia volatilization substantially without compromising productivity. Similarly, reducing $\mathrm{P}$ intake in dairy cattle has been shown to reduce $\mathrm{P}$ excretion by up to $10 \%$. Changing the type of $\mathrm{N}$ and $\mathrm{P}$ consumed and energy level of diet has also been reported to affect the amount and type of $\mathrm{N}$ and $\mathrm{P}$ excreted. Dietary manipulation also has an impact on the amount of GHG emissions, particularly, from enteric fermentation. Feeding cattle with a high starch and low fiber diet, for example, reduces acetate production in the rumen, and leads to lower methane production. Emissions from stored manure from high fiber fed animals tend to be higher. Evidence is also available that diet affects emissions from manure applied soil. As level of production is increased to meet global demand for ruminant meat and milk products, dietary manipulation will be useful in addressing environmental concerns.
\end{abstract}

Key Words: methane, nitrogen, phosphorus, pollution, ruminants

\section{Impacto da manipulação dietética sobre os fluxos de nutrientes e as emissões de gases de efeito estufa na pecuária}

RESUMO - A crescente demanda global por carne, em particular no Brasil, deverá aumentar a produção animal intensiva. Por conseguinte, os principais poluentes são o nitrogênio $(\mathrm{N})$, fósforo (P) e gases de efeito de estufa (GEE). O nitrogênio pode ser um problema devido à lixiviação de nitrato para os corpos d'água, amônia e emissões de óxido nitroso para o ar. Carga de fósforo no solo decorrente da aplicação de esterco pode ser o problema principal, devido à tendência de o $\mathrm{P}$ acumular no solo e atingir os lençóis freáticos e rios. As fontes de emissões de GEE agrícolas incluem metano proveniente da fermentação entérica, armazenagem e e distribuição de estrume e óxido nitroso principalmente da aplicação de adubo na terra. A manipulação dietética tem demomstrado eficiência na redução da poluição de nutrientes/minerais e das emissões de GEE. Vários estudos têm demonstrado que a diminuição de proteína bruta na dieta podem reduzir substancialmente a excreção de $\mathrm{N}$ e a volatilização de amônia, sem comprometer a produtividade. Da mesma forma,a redução da ingestão de $\mathrm{P}$ em bovinos leiteiros pode reduzir a excreção de $\mathrm{P}$ em até $10 \%$. Alterações do tipo de $\mathrm{N}$ e $\mathrm{P}$ consumidos e do nível energético da dieta sobre a quantidade e o tipo de N e P excretado também foram relatadas. A manipulação da dieta também tem impacto sobre a quantidade de emissões de gases de efeito estufa, em particular, a proveniente de fermentação entérica. A alimentação do gado com dietas contendo elevado teor de trigo baixo de fibra, por exemplo, reduz a produção de acetato no rúmen e acarreta menor produção de metano. Emissões decorrentes de estrume de animais alimentados com alto teor de fibra na dieta tendem a ser maiores. Evidenciou-se também que a dieta afeta as emissões de esterco no solo. Em decorrência do aumento do nível de produção para atender à demanda global de carne de ruminantes e produtos lácteos, a manipulação dietética será útil para atender às preocupações ambientais.

Palavras-chave: fósforo, metano, nitrogênio, poluição, ruminantes 


\section{Introduction}

Global demand for meat, particularly in countries with emerging economies such as Brazil, is expected to double by the year 2020 (Mooney et al., 2006), therefore, there is substantial pressure on producers to supply the market. At the same time, there has been a concerted effort to reduce nutrient pollution and greenhouse gas emissions, which has resulted in various international agreements such as the Kyoto protocol and the Copenhagen agreement. Agriculture contributes to nutrient and air pollution in several ways. The main pollutants of interest in relation to ruminant production systems are nitrogen $(\mathrm{N})$ from nitrate leaching and ammonia emissions/deposition, minerals particularly phosphorus (P), greenhouse gases (GHG; carbon dioxide, $\mathrm{CO}_{2}$; methane, $\mathrm{CH}_{4}$ and nitrous oxide, $\mathrm{N}_{2} \mathrm{O}$ ), particulate matter and volatile organic compounds. The scope of this paper will be limited to nutrient/mineral runoff and greenhouse gas emissions. Up to $75 \%$ of costs in livestock operations, especially dairy farming, are incurred in feeding animals, therefore, any reduction in feed prices as a result of either reduced $\mathrm{N}$ and $\mathrm{P}$ concentrations or changes of diet will help farmers increase income. This paper will discuss the impact of dietary manipulation in reducing environmental losses, including recent studies focused on reducing GHG emissions not only from enteric fermentation but also manure and manure-applied soil.

\section{Nutrient and mineral pollution}

\section{Nitrogen}

\section{Reduced overfeeding}

The main source of nutrient pollution from cattle is excess $\mathrm{N}$ excretion. Based on 470 individual cow observations from several calorimetry experiments in the UK. Kebreab et al. (unpublished) found a linear relationship between $\mathrm{N}$ intake and $\mathrm{N}$ in feces, urine and milk (Figure 1). This is in broad agreement with Castillo et al. (2000) and Kebreab et al. (2001). However, for urine $\mathrm{N}$ excretion, the authors reported an exponential relationship, perhaps due to inclusion of data where urine $\mathrm{N}$ was calculated by difference and not directly measured.

According to the analysis $28 \%$ of the $\mathrm{N}$ consumed was excreted in feces, largely due to the undigestible dietary protein fraction, which might not offer opportunities for diet manipulation. About $38 \%$ of $\mathrm{N}$ was excreted in urine, which represents $\mathrm{N}$ that has been absorbed by the animal

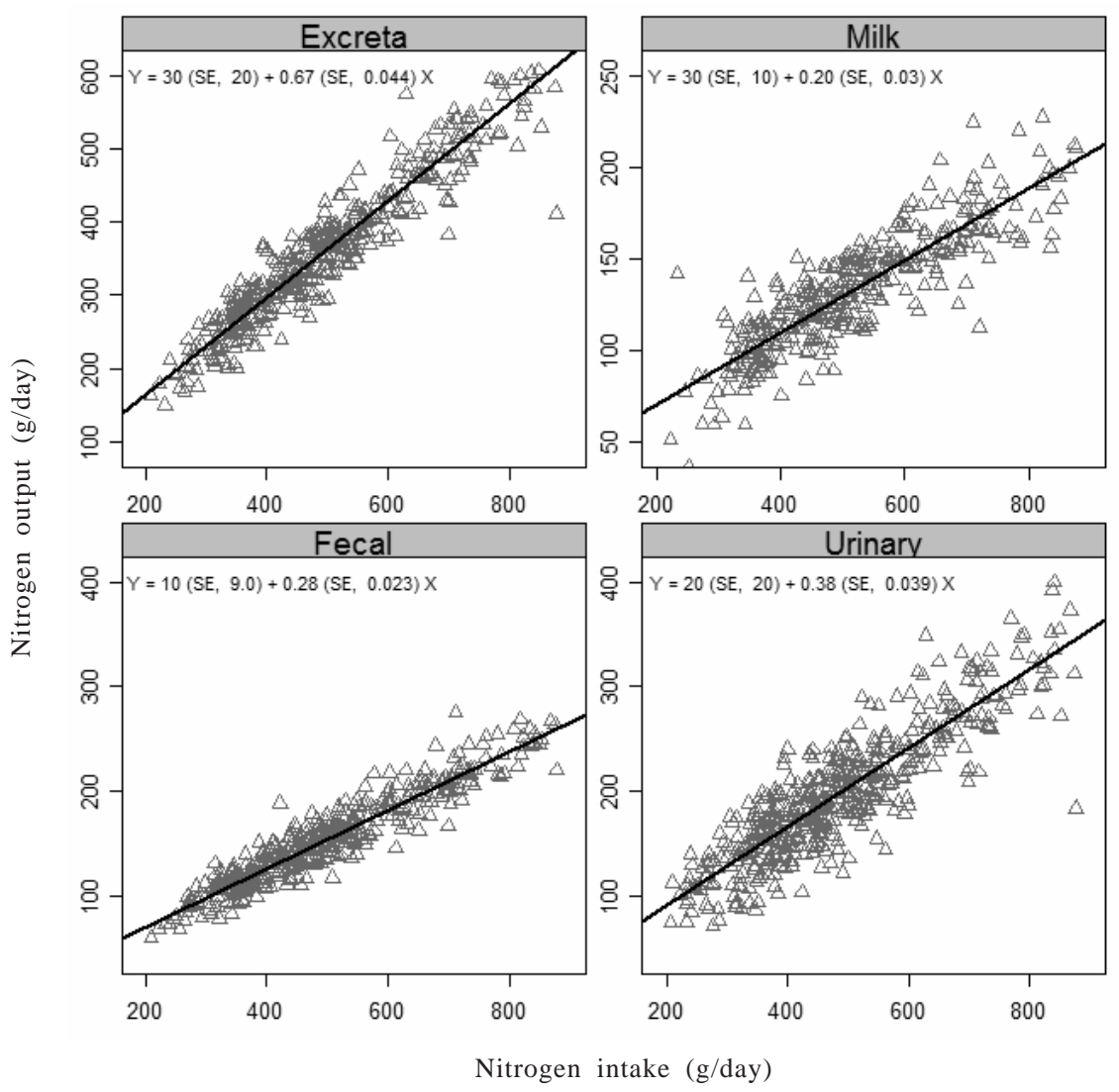

Figure 1 - Relationship between nitrogen intake and nitrogen excretion in feces, urine and milk. Excreta $\mathrm{N}$ is a combination of fecal and urinary $\mathrm{N}$. The responses had been adjusted for study effect. 
but not utilized for growth or milk production. The residual standard deviations for feces, urine and milk $\mathrm{N}$ outputs were estimated to be $14.6,32.5$ and $17.5 \mathrm{~g} / \mathrm{d}$, respectively. The higher residual standard deviation for urine $\mathrm{N}$ compared to fecal or milk output presents an opportunity to manipulate the diet to reduce urine $\mathrm{N}$ excretion. Weiss et al. (2009) also found that increasing protein in the diet linearly increased $\mathrm{N}$ excretion in feces and urine and the variation in excretion of urine $\mathrm{N}$ was 3.5 times greater than the variation in feces $\mathrm{N}$ excretion. The reduction in urine $\mathrm{N}$ is an important way to reduce $\mathrm{N}$ environmental pollution, due to the reduction in ammonia emissions from cattle manure. Urea from urine will be converted to ammonia due to the high urease activity of feces (Muck, 1982).

Castillo et al. (2001b) reported that it is possible to improve $\mathrm{N}$ utilization in dairy cows by decreasing protein intake from balanced diets. A reduction of protein concentration from 19 to $15 \%$ for example can reduce $\mathrm{N}$ excreted in urine substantially without compromising lactational performance. Furthermore, the authors calculated that when total ration protein levels were reduced, total excreted $\mathrm{N}$ levels fell from 15.2 to $12.3 \mathrm{~g} / \mathrm{kg}$ milk produced and, if such results could be imposed in normal livestock systems, they would represent a net reduction in $\mathrm{N}$ excretion from 106 to 86 tonnes/yr for 1000 dairy cows producing average milk yields of 7,000 kg/yr.

Type of energy and protein sources

Castillo et al. (2001a) investigated the effect of energy supplementation on efficiency of $\mathrm{N}$ utilization in an experiment using isoenergetic diets containing different quantities of soluble carbohydrates, fibre, and starch. Overall efficiency rarely exceeded $0.30 \mathrm{~g}$ milk/g of dietary $\mathrm{N}$ intake. Total fecal $\mathrm{N}$ excretion and proportion of apparent fecal $\mathrm{N}$ were unaffected by type of energy source supplemented. Similar results were presented by Weiss et al. (2009), where Holstein cows were fed diets with different carbohydrates sources and distinct metabolizable protein contents. Treatments with more alfalfa gave an increased fecal $\mathrm{N}$ excretion and decreased urinary $\mathrm{N}$ excretion. This supports the argument that $\mathrm{N}$ excreted in feces as a proportion of $\mathrm{N}$ intake is relatively constant because it consists of mainly undigested material and metabolic fecal $\mathrm{N}$. The most pronounced effect in the experiment of Castillo et al. (2001a) was the increase in urinary $\mathrm{N}$ excretion of cows fed a diet with high degradable starch. It is possible that, due to increase in the rate of starch degradation in the rumen, some of the $\mathrm{N}$ was absorbed as ammonia and excreted in urine or more amino acids were absorbed but deaminated and excreted in urine. Cows fed a diet supplemented with low degradable starch had lower urinary $\mathrm{N}$ excretion. This could have been due to a more efficient utilization of ruminal ammonia-N which otherwise would have been absorbed from the rumen, converted to urea in the liver and then most likely excreted in urine (Kebreab et al., 2001).

In addition to reducing crude protein (CP) concentration, it has been recognized that type of protein supplement has an effect on the efficiency of $\mathrm{N}$ utilization. Castillo et al. (2001b) examined the effects of supplementing diets with various levels of protein degradability and concentration on efficiency of $\mathrm{N}$ utilization in dairy cattle. The authors offered six diets comprising three levels of protein degradability in the concentrate and two levels of CP (21 and 29\%). Protein degradability did not have an effect on fecal $\mathrm{N}$ outputs. This confirms the results of an earlier experiment with various sources of energy as supplements. After analyzing the composition of fecal $\mathrm{N}$ output in lactating dairy cows, Tamminga (1992) concluded that a reduction in fecal excretion of indigestible feed protein was not the most promising way to achieve substantial reductions in $\mathrm{N}$ loss by the animal. Little improvement in digestibility is possible because true digestibility of feed protein in dairy cow rations is generally high. Castillo et al. (2001b) observed a significant increase of urinary $\mathrm{N}$ with the higher degradable protein-supplemented diet, but the rates at which urinary $\mathrm{N}$ increased with increasing CP degradability were much greater on the high-CP compared with the low CP diet. The authors argued that this was probably due to decreased efficiency of $\mathrm{N}$ capture by microbes in the rumen as the relative rate of degradation of the potentially degradable fraction of CP in the diet is increased, leading to an increase in urinary $\mathrm{N}$ output.

\section{Ammonia emissions from cattle manure}

Nitrogen excretion in the ruminant animal is basically composed of undegradable protein, endogenous material, microbial protein that escapes digestion, urine urea, and other $\mathrm{N}$ components in urine. Urea is produced mainly in the liver to eliminate excess ammonia present in blood. Ammonia in blood is a result of deamination of amino acids in animal tissues. In ruminants, ammonia in circulation can also come from microbial degradation of $\mathrm{N}$ compounds (DePeters \& Ferguson, 1992). Urea in contact with urease, an enzyme produced by microorganisms found in both feces and in soil (Muck, 1982), is converted to ammonia and then volatilized. The process of ammonia volatilization occurs by mass transfer from the top layer of the manure slurry to the air surrounding the manure surface. The mass transfer is dependent of temperature and air velocity at the manure top layer (Zhang et al., 2005). 
Dietary protein excess can increase $\mathrm{N}$ excretion in manure, especially in urine, increasing ammonia volatilization. A number of studies have shown that the amount of ammonia produced from cattle manure is correlated with N intake (Burgos et al., 2010, James et al., 1999). The hydrolysis of urea to ammonia under manure $\mathrm{pH}$ is an irreversible reaction (Muck, 1982) and urease activity is high in most milk and meat production systems where a high density of animal per unit of space is used, i.e. in dairies (Monteny \& Erisman, 1998). Therefore the amount of ammonia emitted should be determined by its production rate (Muck, 1982).

In the study by Burgos et al. (2010) ammonia emissions were measured for cows consuming diets ranging from $15 \%$ to $21 \%$ CP. The results showed that the amount of urea in manure increased linearly with dietary $\mathrm{CP}$ and was almost 3 times higher in manure from cows consuming a $21 \%$ CP diet when compared to the $15 \%$ CP cows. No significant differences were found in the total amoniacal $\mathrm{N}$ in manure of different treatments at zero time but there were differences after 24 hours. Ammonia emissions, as expected (James et al., 1999; van der Stelt et al., 2008), were proportional to the amount of urea excreted in manure, and ranged from 57 to $149 \mathrm{~g}$ of N/d per cow, giving a linear relationship with CP content of the diet (Burgos et al., 2010).

Ammonia emissions from manure applied to soil as fertilizer are also linked to atmospheric pollution, and can reduce the nutrient value of manure (Muck, 1982). Misselbrook et al. (2005) evaluated ammonia emissions from manure of cows receiving diets with $14 \%$ and $19 \%$ CP. Emissions of fresh manure applied to soil were significantly greater for cows on the 19\% CP diet, both in grams and expressed as a percentage of the initial total amoniacal $\mathrm{N}$ in manure. However, ammonia emissions were similar for both diets when expressed as a proportion of total manure $\mathrm{N}$.

\section{Phosphorus}

There are two ways in which dietary manipulation can reduce $P$ excretion in ruminants. In all species of livestock, $P$ fed in excess of animal requirements is excreted, making reducing overfeeding a powerful tool to increase efficiency of utilization. The second method is increasing the energy density of diet which will be discussed later.

In dairy cows, several studies indicate a direct link between P intake and P excretion (e.g. Morse et al., 1992; Wu et al., 2000, 2001; Knowlton et al., 2001; Knowlton and Herbein, 2002). A Florida study was among the first to show this link (Morse et al., 1992). Twelve cows were fed diets containing one of three concentrations of $\mathrm{P}(0.30 \%, 0.41 \%$, or $0.56 \%$ of dietary DM). Excretion increased linearly with increasing $\mathrm{P}$ intake, and accounted for nearly all of the difference in $\mathrm{P}$ intake with the high $\mathrm{P}$ diet compared with the low $P$ diet.

Overfeeding of dietary $\mathrm{P}$ is common in the field. In the past, $\mathrm{P}$ was often fed to dairy cattle 20 to $40 \%$ in excess of published requirements (Shaver \& Howard, 1995; Sink et al., 2000). A survey conducted by Wu (2003) in Pennsylvania indicated that the extent of overfeeding is less now than was suggested in these earlier surveys. In growing beef cattle, Erickson et al. (1999) reported an industry average dietary P content of 0.35 to $0.39 \%$ of DM, compared with published requirements for growing steers of about $0.20 \%$ P. Kebreab et al. (2008) conducted a survey in Ontario, Canada and found that dairy farmers were, on average, using $0.41 \% \mathrm{P}$ in the diet. The authors evaluated a dynamic model based on experiments conducted in Ontario (Odongo et al., 2007a) and reported that reduction of P to NRC (2001) recommended concentrations would save farmers $\$ 20 / \mathrm{cow}$ annually. Moreover, excretion of $\mathrm{P}$ would be reduced by 1.3 kt/year from Ontario dairy farms according to model calculations (Kebreab et al., 2008). Estimates of savings in feed cost assume that the excess dietary $P$ is from purchased mineral sources; if excess $\mathrm{P}$ is from inexpensive by-product feeds, reducing dietary P may increase feed costs.

Kebreab et al. (2005) showed that although fecal P and dietary $\mathrm{P}$ were linearly related, the type and density of energy in the feed have a significant effect on P excretion (Figure 2). In comparing two experiments with high and low energy intake, Kebreab et al. (2005) found that P efficiency improved significantly in cows fed the higher energy diet (consuming an extra $30 \mathrm{MJ} / \mathrm{d}$ or more). They surmised that the increased efficiency could be due to higher P uptake by microbes in the rumen and higher conversion of dietary $\mathrm{P}$ to milk and body tissues.

Greenhouse gas emissions

\section{Methane}

\section{Enteric fermentation}

Feed digested by cattle delivers energy and nutrients to the animal for maintenance and productive purposes. The process of digesting feed in the rumen involves conversion of organic matter to volatile fatty acids and hydrogen gas. Most of the hydrogen is utilized by methanogens and converted in to methane and water. The amount of methane produced depends largely on the amount of food consumed (Reynolds et al., 2009; Fig 3), and the characteristics and composition of the feed. The chemical composition of the fermented fractions of feed determines the amount and type of volatile fatty acids 


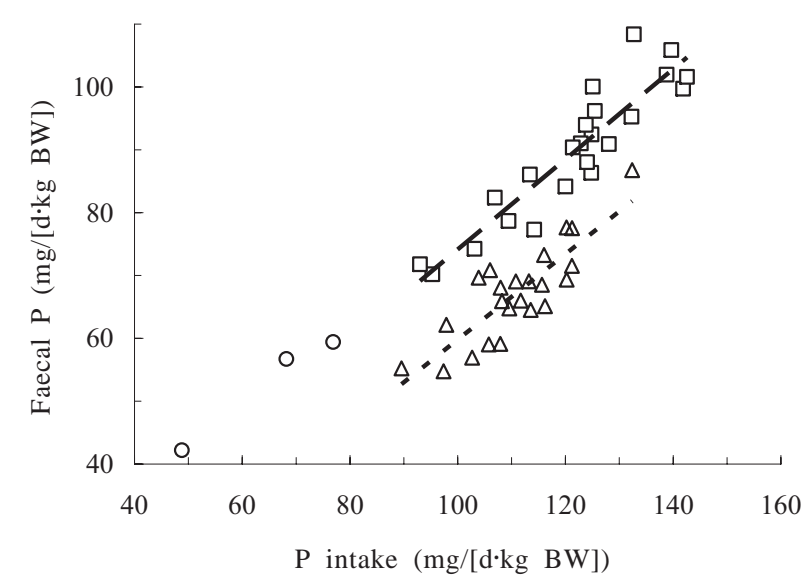

Figure 2 - Relationship between P intake (PI, mg/[day·kg BW]) and fecal $\mathrm{P}$ (FP, $\mathrm{mg} /[$ day $\cdot \mathrm{kg}$ body weight]) in lactating ewes (O) (data from Braithwaite, 1986) and dairy cows fed low $(\square)$ and high energy diet $(\Delta)$. The fitted lines were as follows: $\mathrm{FP}$ in ewes $=9.4+0.68(\mathrm{PI})$ ( $\mathrm{SE}=4.88$ and 0.07 for the intercept and slope, respectively; $\left.\mathrm{r}^{2}=0.98\right)$, $\mathrm{FP}$ in cows in Exp. $1=2.1+$ $0.72(\mathrm{PI})(\mathrm{SE}=7.81$ and 0.07 for the intercept and slope, respectively; $\left.\mathrm{r}^{2}=0.84\right)$ and $\mathrm{FP}$ in cows in Exp. $2=-8.3+0.68(\mathrm{PI})(\mathrm{SE}=6.58$ and 0.06 for the intercept and slope, respectively; $\mathrm{r}^{2}=0.71$ ) $\mathrm{x}$ (Adapted from Kebreab et al., 2005).

and the quantity of hydrogen gas produced (Kebreab et al., 2009).

Measurement of methane production in animals requires complex and often expensive equipment; therefore, prediction equations are widely used to estimate methane emission. Some models have been developed specifically to predict emissions from animals (Mills et al., 2003; Ellis et al., 2007) and others have been either modified or adapted to estimate methane emission from rumen fermentation (e.g. Dijkstra et al., 1992). Empirical and mechanistic models of enteric fermentation show that feed intake is the main determinant of methane emission (Figure 3), and can account up to $74 \%$ of methane emission (Ellis et al., 2007).

A quarter of the variances can be attributed to differences in diet composition and error terms. Forage proportion, lignin, neutral detergent fibre and acid detergent fibre contents of diet where found to be positively correlated with methane production (Ellis et al., 2007), which were in agreement with Mills et al. (2001) who reported that replacing fiber sources with starch reduced the amount of methane emissions. The authors attributed the differences to higher propionate and lower acetate production associated with starch fermentation compared to fiber

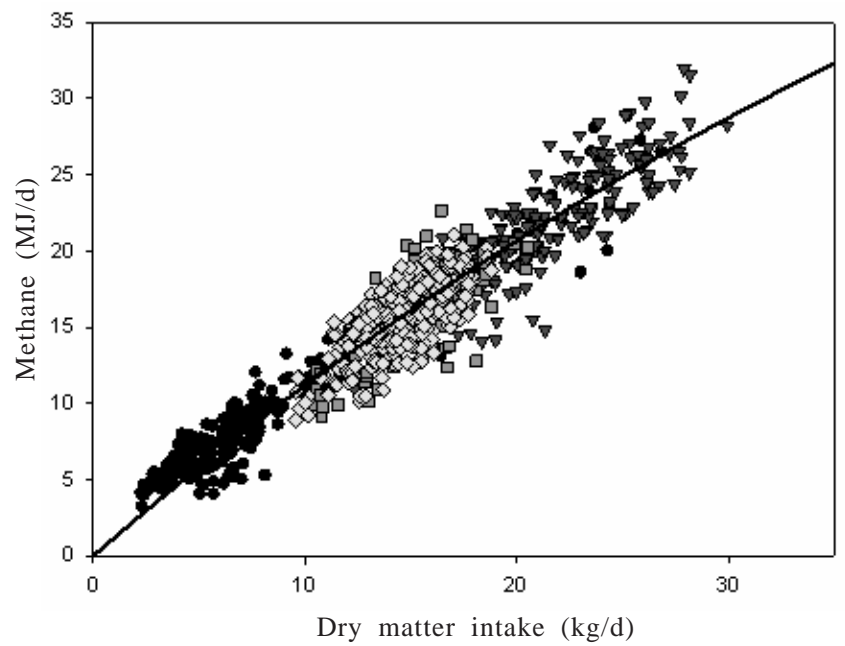

Figure 3 - Relationship between dry matter intake $(\mathrm{kg} / \mathrm{d})$ and methane excretion $(\mathrm{MJ} / \mathrm{d})$ in beef and dairy cattle after correction for trial effects. Symbols represent different trials (After Reynolds et al., 2009).

digestion. Addition of fats to the diet (less than 5\%) was also found to decrease the amount of methane produced due to a shift away from fiber digesting bacteria and hence less methane. To a lesser extent lipids also act as alternative hydrogen sinks and compete with methanogens for hydrogen in the rumen (Kebreab et al., 2006). Similarly, ionophores such as monensin also reduce methane emissions, although the effect is normally short lived (about 4 -6 weeks) before the microbial community adapts to the treatment (Odongo et al., 2007b).

\section{Manure management and land application}

Kebreab et al. (unpublished) fed animals three diets which had different fiber contents (low, medium, and high fiber content). They collected the manure from the animals and incubated them in three replicate fermenters and measured methane production daily. The cumulative methane emissions from the fermenters fed with three different manures are given in Figure 4. The researchers achieved different manure compositions from the treatments. The effect of diet on methane emissions was not apparent in the first 45 days. However, after 45 days the fermenters fed manure from animals that had consumed a high fiber content diet started to produce more methane. There was no difference in cumulative methane emissions in fermenters fed with either medium or low fiber content manure (Figure 4). The experiment showed that higher organic matter in manure especially in the form of fiber contributes to higher methane emissions from stored manure. 


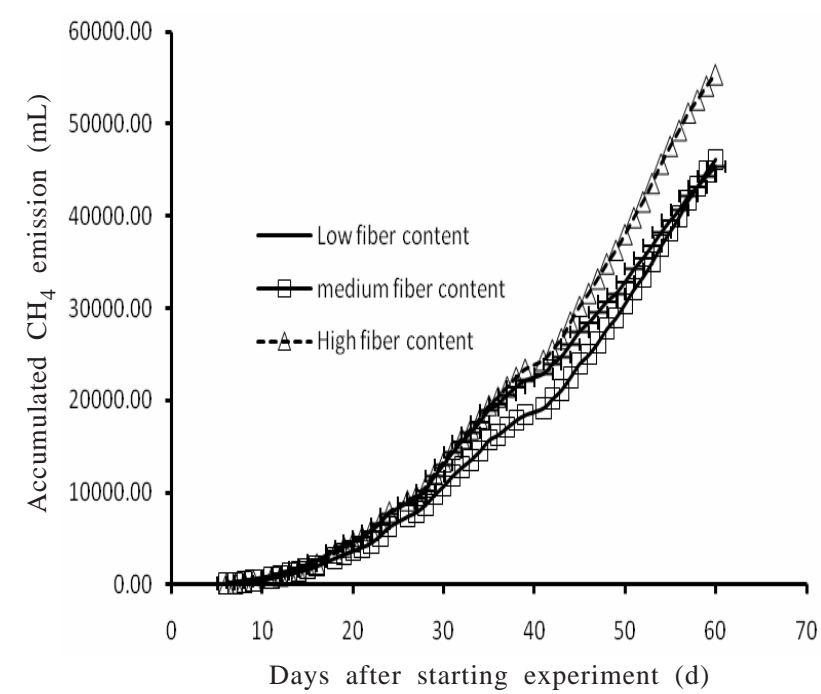

Figure 4 - Time course of accumulated $\mathrm{CH}_{4}$ emissions from fermenters fed three different manures (Huang et al., unpublished).

In another experiment, Kebreab et al. (unpublished) applied manure collected from cattle fed low quality forage on its own or supplemented with dried distillers' grain and solubles to soil in Manitoba, Canada. To help comparison of emissions using the same scale, the authors calculated carbon dioxide equivalent $\left(\mathrm{CO}_{2}\right.$ eq) emissions by multiplying the amount of $\mathrm{CH}_{4}$ and $\mathrm{N}_{2} \mathrm{O}$ produced by their global warming potentials of 21 and 310 respectively. Based on $\mathrm{CO}_{2} \mathrm{e}$, the authors showed that quality of feed given to cattle had an effect on manure composition and GHG emissions after the manure has been applied to soil (Table 1).

Table 1 - Effect of cattle manure from various feed type (with or without dried distillers' grains and solubles, DDGS) on greenhouse gas emissions (GHG, expressed in $\mathrm{CO}_{2}$ equivalents, $\mathrm{CO}_{2} \mathrm{e}$ ) after applied on soils in Manitoba, Canada

\begin{tabular}{lc}
\hline Treatment & $\begin{array}{c}\text { GHG emission } \\
\mathrm{gCO}_{2} \mathrm{e}(\mathrm{kg} \mathrm{soil})^{-1} \mathrm{~h}^{-1}\end{array}$ \\
\hline Control & $0.864 \mathrm{a}$ \\
Low quality forage with no DDGS & $0.808 \mathrm{a}$ \\
Low quality forage with 10\% DDGS & $0.781 \mathrm{a}$ \\
Low quality forage with 20\% DDGS & $0.673 \mathrm{~b}$
\end{tabular}

Column values followed by the same letter are not significantly different by Waller-Duncan test at $5 \%$ probability.

\section{Conclusions}

Dietary manipulation has been shown to have an impact in mitigating nutrient pollution and greenhouse gas emissions from livestock operations. Reduction in $\mathrm{N}$ excretion can be achieved not only by reducing $\mathrm{N}$ content in the diet but also changing the type of protein in feed. Similarly, excess $P$ excretion can be avoided by matching the animal's requirement with supply in diet; and improving energy content of diet so that $\mathrm{P}$ can be utilized more efficiently. Replacing fibrous diets by starchy feedstuff has been shown to reduce methane from enteric fermentation and manure storage. Further research need to be conducted to quantify the impact of dietary manipulation holistically on the farm, i.e. animal, manure and soil.

\section{References}

BRAITHWAITE, G.D. Phosphorus requirements of ewes in pregnancy and lactation. Journal of Agricultural Science, v.106, p.271-278, 1986.

BURGOS, S.A.; EMBERTSON, N.M.; ZHAO, Y. et al. Prediction of ammonia emission from dairy cattle manure based on milk urea nitrogen: relation of milk urea nitrogen to ammonia emissions. Journal of Dairy Science, 2010 (in press).

CASTILLO, A.R.; KEBREAB, E.; BEEVER, D.E. et al. The effect of energy supplementation on nitrogen utilization in lactating dairy cows fed grass silage diets. Journal of Animal Science, v.79, p.240-246, 2001a.

CASTILLO, A.R.; KEBREAB, E.; BEEVER, D.E. et al. The effect of protein supplementation on nitrogen utilisation in grass silage diets by lactating dairy cows. Journal of Animal Science, v.79, p.247-253, 2001b.

CASTILLO, A.R.; KEBREAB, E.; BEEVER, D.E. et al. Review of efficiency of nitrogen utilisation in dairy cows and its relationship with the environmental pollution. Journal of Animal and Feed Sciences, v.9, p.1-32, 2000.

DEPETERS, E.J.; FERGUSON, J.D. Nonprotein nitrogen and protein distribution in the milk of cows. Journal of Dairy Science, v.75, p.3192-3209, 1992.

DIJKSTRA, J.; NEAL, H.D.ST.C.; BEEVER, D.E. et al. Simulation of nutrient digestion, absorption and outflow in the rumen: Model description. Journal of Nutrition, v.122, p.2239-2256, 1992.

ELLIS, J.L.; KEBREAB, E.; ODONGO, N.E. et al. Prediction of methane production from dairy and beef cattle. Journal of Dairy Science, v.90, p.3456-3467, 2007.

JAMES, T.; MEYER, D.; ESPARZA, E. et al. Effects of dietary nitrogen manipulation on ammonia volatilization from manure from holstein heifers. Journal of Dairy Science, v.82, p.2430-2439, 1999.

KEBREAB, E.; CLARKE, K.; WAGNER-RIDDLE, C. et al. Methane and nitrous oxide emissions from Canadian animal agriculture a review. Canadian Journal of Animal Science, v.86, p.135158, 2006.

KEBREAB, E.; DIJKSTRA, J.; BANNINK, A. et al. Advances in modeling ruminant nutrient utilization. Journal of Animal Science, v.87, E Supplement, p.E111-E122, 2009.

KEBREAB, E.; FRANCE, J.; BEEVER, D.E.; CASTILLO, A.R. Nitrogen pollution by dairy cows and its mitigation. Nutrient Cycling in Agroecosystems, v.60, p.275-285, 2001. 
KEBREAB, E.; FRANCE, J.; SUTTON, J.D.et al. Effect of energy and protein supplementation on phosphorus utilization in lactating dairy cows. Journal of Animal and Feed Sciences, v.14, p.63-77, 2005

KEBREAB, E.; ODONGO, N.E.; MCBRIDE, B.W. et al. Phosphorus utilization and environmental and economic implications of reducing phosphorus pollution from Ontario dairy cows. Journal of Dairy Science, v.91, p.241-246, 2008.

KNOWLTON, K.F.; HERBEIN, J.H.; MEISTER-WEISBARTH, M.A. et al. Nitrogen and phosphorus partitioning in lactating Holstein cows fed different sources of dietary protein and phosphorus. Journal of Dairy Science, v.84, p.1210-1217, 2001.

KNOWLTON, K.F.; HERBEIN, J.H. Phosphorus balance during early lactation in dairy cows fed diets varying in phosphorus content. Journal of Dairy Science, v.85, p.1227-1236, 2002.

MILLS, J.A.N; KEBREAB, E.; YATES, C. et al. Alternative approaches to predicting methane emissions from dairy cows. Journal of Animal Science, v.81, p.3141-3150, 2003.

MILLS, J.A.N; DIJKSTRA, J.; BANNINK, A. et al. A mechanistic model of whole-tract digestion and methanogenesis in the lactating dairy cow: Model development, evaluation, and application. Journal of Animal Science, v.79, p.1584-1597, 2001

MISSELBROOK, T.H.; POWELL, J.M.; BRODERICK, G.A. et al. dietary manipulation in dairy cattle: laboratory experiments to assess the influence on ammonia emissions. Journal of Dairy Science, v.88, p.1765-1777, 2005.

MONTENY, G.J.; ERISMAN, J.W. Ammonia emissions from dairy cow buildings: a review of measurement techniques, influencing factors and possibilities for reduction. Netherlands Journal of Agricultural Science, v.46, p.225-247, 1998.

MOONEY, H.A.; NAYLOR, R.L.; FALCON, W.P. [2006]. Consequences of increased global meat consumption on the global environment - trade in virtual water and nutrients. Available on: <http://foodsecurity.stanford.edu/ research/consequences_of_increased_global_meat_ consumption on $_{-}$the $e_{-}$global_environment_ trade_in_virtual_water_and_nutrients>.

MORSE, D.; HEAD, H.H.; WILCOX, C.J. Disappearance of phosphorous in phytate from concentrates in vitro from rations fed to lactating dairy cows. Journal of Dairy Science, v.75, p.1979-1986, 1992.

MUCK, R.E. Urease activity in bovine feces. Journal of Dairy Science, v.65, p.2157-2163, 1982
NATIONAL RESEARCH COUNCIL - NRC. Nutrient requirements of dairy cattle. 7.ed. Washington, D.C.: National Academy Press, 2001.

ODONGO, N.E.; OR-RASHID, M.M.; HOOK, S.E. et al. Longterm effects of feeding monensin on methane production in lactating dairy cows. Journal of Dairy Science, v.90, p.17811788, 2007b

ODONGO, N.E.; MCKNIGHT, D.; KOEKKOEK, A. et al. Longterm effects of feeding diet without mineral phosphorus supplementation on the performance and phosphorus excretion in high yielding dairy cows. Canadian Journal of Animal Science, v.87, p.639-646, 2007a.

REYNOLDS, C.K.; CROMPTON, L.A.; MILLS, J.A.N. Improving the efficiency of energy utilization in cattle. Winnipeg: 2009. p.55-65.

SHAVER, R.; HOWARD, W.T. Are we feeding too much phosphorus? In: Hoards Dairyman, 1995. p.280-281.

SINK, S.E.; KNOWLTON, K.F.; HERBEIN, J.H. Economic and environmental implications of overfeeding phosphorus on Virginia dairy farms. Journal of Animal Science, v.78, Supplemental 2, p.4, 2000.

VAN DER STELT, B.; VAN VLIET, P.C.J.; REIJS, J.W. et al. Effects of dietary protein and energy levels on cow manure excretion and ammonia volatilization. Journal of Dairy Science, v.91, p.4811-4821, 2008.

WEISS, W.P.; WILLET, L.B.; ST-PIERRE, N.R. et al. Varying forage type, metabolizable protein concentration, and carbohydrate source affects manure excretion, manure ammonia, and nitrogen metabolism of dairy cows. Journal of Dairy Science, v.92, 5607-5619, 2009.

WU, Z. People still are feeding too much phosphorus. Hoards Dairyman, v.148, p.210, 2003.

WU, Z.; SATTER, L.D.; BLOHOWIAK, A.J. et al. Milk production, estimated phosphorus excretion, and bone characteristics of dairy cows fed different amounts of phosphorus for two or three years. Journal of Dairy Science, v.84, p.1738-1748, 2001

WU, Z.; SATTER, L.D.; SOJO, R. Milk production, reproductive performance, and fecal excretion of phosphorus by dairy cows fed three amounts of phosphorus. Journal of Dairy Science, v.83, p.1028-1041, 2000

ZHANG, R.; RUMSEY, T.; FADEL, J.G. et al. Development of an improved process based ammonia emission model for agricultural sources. Lake Michigan Air Directors Consortium, Des Plaines: Illinois, 2005. 